\title{
Fiscal Policy Tools and Economic Growth in Jordan: Evidence from Time-Series Models
}

\author{
Mohamed Ibrahim Mugableh ${ }^{1}$ \\ ${ }^{1}$ Head Department of Financial and Banking Sciences, College of Administrative and Financial Sciences, Irbid \\ National University, Jordan \\ Correspondence: Mohamed Ibrahim Mugableh, Head Department of Financial and Banking Sciences, College of \\ Administrative and Financial Sciences, Irbid National University, P.O Box: 2600-Zip Code: 21110, Jordan. Tel: \\ 962-790-956-497. E-mail: mugableh83@yahoo.com or dr.magableh@inu.edu.jo
}

Received: October 14, 2018

Accepted: November 12, 2018

Online Published: December 2, 2018

doi:10.5539/ijef.v11n1p1

URL: https://doi.org/10.5539/ijef.v11n1p1

\begin{abstract}
This paper examines equilibrium relationships and dynamic causality analyses between economic growth and fiscal policy tools in Jordan for the (1978-2017) period. It employs autoregressive distributed lag and vector error correction models. The results suggest that there is evidence of a co-integration and causal relationships between economic growth and fiscal policy instruments. General government expenditures have long-run positive impact on economic growth, implying that general government expenditures improve economic growth. Moreover, total tax rates have long-run negative impact on economic growth, implying that a tax cut stimulates economic growth. These results are broadly consistent with similar studies carried out for other developing economies.
\end{abstract}

Keywords: econometrics, economic growth, fiscal policy, Jordan

\section{Introduction}

Fiscal policy and monetary policy are used to achieve macroeconomic objectives in a nation. These objectives include reduction in a nation's debt, sustainable economic growth, reduction of poverty levels, full employment, and inflation rate stability. The Jordan's potential for achieving macroeconomic objectives is yet to be realized. Consumer price index $(2010=100)$ as a measurement of inflation rate has increased from 68.43 in 2001 to 119.34 in 2017 (World Bank Database, 2018). Unemployment is a major economic and political concern in most countries. On the average, the unemployment rate was 15\% between the years 2001 and 2017 (World Bank Database, 2018). Jordan's Gross Domestic Product (GDP) growth between 2000 and 2009 averaged 6.5\%, but from 2010 until 2016, average growth was a mere 2.5\%. Moreover, Jordan's total public debt has increased at a rate exceeding economic growth. This has resulted in a debt-to-GDP ratio of $95 \%$ at the end of 2016, compared to approximately $61 \%$ in 2010 (Jordan Economic Growth Plan (JEGP) Report, 2018).

However, the combination of the global financial crisis of 2009, Arab spring regional turbulence, energy crisis, closure of trade routes resulting in de facto economic siege (Exports to Iraq amounted to $20 \%$ of Jordan's total exports), a decline in remittances, security costs, and increasing food and oil prices has put a significant stain on Jordan's economic and fiscal drive (Bekhet \& Al-Smadi, 2017; Bekhet \& Matar, 2013). A successful implementation of the International Monetary Fund (IMF) Extended Fund Facility (EFF) program and the JEGP will achieve macroeconomic objectives. According to the JEGP (2018-2022) report, Jordan and the IMF agreed to a USD 723 million EFF in order to lower debt levels and fiscal imbalance.

The issue of the relationships between economic growth and fiscal policy tools has been diversely investigated (e.g., Arai, Naito, \& Ono, 2018; Ding, McQuoid, \& Karayalcin, 2018; Lim \& McNelis, 2018; Biolsi, 2017; Mencinger, Aristovnik, \& Verbic, 2017; Attinasi \& Klemm, 2016; Yang, 2016; Yushkov, 2015). In the case of a developing economy, Jordan, few researchers examined the relationships between fiscal policy tools and economic growth (e.g., Al-Fawaz, 2016; Abu Shihab, 2014; Al-Shatti, 2014; Hamdi, Alawin, \& Abu Mhareb, 2009). However, the main objective of the current paper is to re-estimate the hypotheses of equilibrium relationships and dynamic causality analyses between economic growth and fiscal policy tools in Jordan. To the best of the author's knowledge and belief, the originality of this paper stems from three scopes. First, it employs Autoregressive Distributed Lag (ARDL) approach to examine equilibrium (i.e., long-run and short-run) 
relationships between economic growth and fiscal policy tools. Second, it utilizes Vector Error Correction Model (VECM) to investigate dynamic causality between economic growth and fiscal policy instruments. Third, it uses long span of the Jordan's annual time-series data in constant 2010 bases for the (1978-2017) period.

The remainder of the paper is organized as follows. Section 2 presents a brief literature review related to economic growth and fiscal policy tools. Section 3 describes the data and theoretical model. Econometrics methodology and results analysis are given in Section 4, while the conclusions and policy recommendations are outlined in Section 5.

\section{Review of Related Literature}

Fiscal policy is based on the Keynesian economic theory which states that governments can influence economic growth by increasing or decreasing tax levels and public spending. This influence, in turn, maintains a healthy value of money, controls inflation, and increases employment. Numerous studies have examined different aspects of fiscal policy especially as it relates to economic growth. Papaioannou (2018) analyzed the influence of public expenditure on economic growth using Markov Switching regression and quarterly data for Greece. The results showed that the effects of government spending on economic growth are asymmetric over the business cycle. Madni and Chaudhary (2017) investigated the relationship among economic growth, institutional quality, and fiscal policy over the period (1984-2015), in the case of Pakistan. The ARDL approach was employed to determine the long-run and short-run relationship among the variables. Principal Component Analysis was carried out to construct an index for institutional quality. It was found that institutional quality and government spending were positively affecting economic growth, while educational attainment and private investment were significantly contributing to enhance economic growth. Osebo (2017) examined the impact of fiscal policy variables on economic growth for Ethiopia over the period (1974-2013). The fiscal policy variables are government expenditure, revenue, and budget balance. The results of VECM indicated that economic growth and fiscal policy variables had long run relationship. Moreover, the capital expenditure, direct tax and budget balance had positive relationship with economic growth in the long run.

Cyril (2016) investigated the effects of fiscal policy instruments on the Nigerian economy for the period (1985-2015). Descriptive statistics and ordinary least square methods had been employed after ensuring data stationary. The results showed that public expenditures on economic services (agriculture, construction, transport, and communication) had enormous returns to economic stability and growth. Jawadi, Mallick, and Sousa (2016) employed a panel Vector Autoregressive (VAR) model to assess the impact of fiscal policy and monetary policy shocks in economic activity for five key emerging economies-Brazil, Russia, India, China, and South Africa. The results showed that monetary contractions led to a fall in real economic activity and tighten liquidity market conditions, while government spending shocks had strong Keynesian effects. Ialomitianu, Danu, and Bucoi (2016) highlighted and explored efficient fiscal consolidation strategies that can ensure a stable economic growth through sustainable public finances. The conclusion they reached was that, in order to restore the sustainability of public finances, the need arises for considerable fiscal consolidation effort, as well as for deep structural reforms, with a view to creating favorable conditions for sustainable economic growth.

Shoayeb, Noman, and Khudri (2015) examined the impact of fiscal and monetary policies on economic growth in Bangladesh. The study concluded that exchange rate, interest rate, inflation rate, government revenue, and government expenditure significantly affected economic growth in Bangladesh. Bouakez, Chihi, and Normandin (2014) examined the effects of fiscal policy tools on the US economy before and after 1979. The results revealed that increases in public spending are in general more effective than tax cuts in stimulating economic activity. Ocran (2010) examined the effects of fiscal policy instruments (i.e., government expenditures, tax revenues, and budget deficit) on the South African economy. The structural VAR model was employed and quarterly data for the period (1990-2008). The results showed that tax revenues and budget deficit had positive effects on economic growth, while government investment and consumption expenditures had negative effects.

Hernandez de Cos and Castro (2008) estimated the effects of exogenous fiscal policy shocks in Spain in a VAR framework. Government expenditure expansionary shocks were found to have positive effects on output in the short-term at the cost of higher inflation and public deficits, and lower output in the medium and long term. Tax increases were found to drag economic activity in the medium term while entailing an only temporary improvement of the public budget balance. Auteri and Costantini (2004) examined the relationship between fiscal policy and economic growth in Italy for the period (1970-1995). The results revealed a positive influence of public investments on economic growth.

\section{Data and Theoretical Model}

For the purpose of this study, annual time-series data for the (1978-2017) period has been compiled from the 
World Bank (2018) database, which covers the variables of economic growth and fiscal policy. The current paper uses the GDP (Billion JD) to measure economic growth. The variables of fiscal policy are General Government Expenditures (GGE, Billion JD) and Total Tax Rate (TXR, \% of commercial profits). The general form of the model can be written as in Eq. (1):

$$
G D P=f(G G E, T X R)
$$

Eq. (1) is linear and can be converted into log-linear formulation as in Eq. (2) to avoid estimation problems, particularly variations, heteroscedasticity, and multicollinearity (Mugableh, 2018a; Mugableh \& Oudat, 2018b; Mugableh \& Oudat, 2018c; Mugableh, 2017a; Mugableh, 2017b; Bekhet and Mugableh, 2016; Mugableh, 2015a; Mugableh, 2015b; Mugableh, 2015c; Bekhet and Mugableh, 2013; Mugableh, 2013; Bekhet and Mugableh, 2012).

$$
\log G D P_{t}=\alpha_{0}+\alpha_{1} \log G G E_{t}+\alpha_{2} \log T X R_{t}+\varepsilon_{t}
$$

Where, $\varepsilon_{\mathrm{t}}$ is the white noise term distributed with zero mean and constant variance. Based on the Keynesian economic theory, the signs of coefficients are expected to be as follows: $\alpha_{1}>0$ and $\alpha_{2}<0$. A positive relationship is hypothesized between economic growth and general government expenditures, while a negative relationship is hypothesized between economic growth and total tax rate. In a context of Keynesian economic theory, an expansionary fiscal policy aims to stimulate the economy can be done either by increasing government expenditure or by a tax cut or both. But, if this policy failed to achieve the desired growth rate then, the government will not get the desired tax revenue collection to finance government spending in the next period.

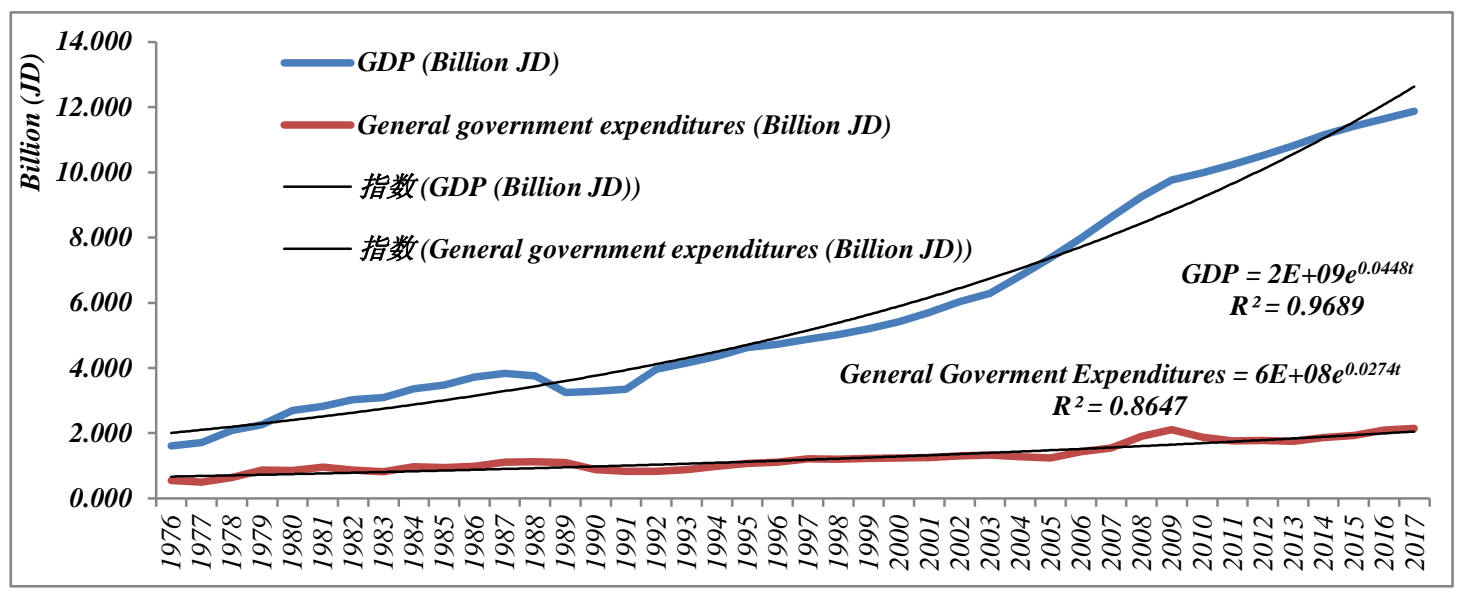

Figure 1. Growth rates of GDP and general government expenditures in Jordan for the (1976-2017) period

Growth rates of the GDP and general government expenditures are shown in Figure 1. It is very clear that growth rate of the GDP presents a highly symmetric behaviour for the (1976-2017) period, with average of $4.5 \%$. Similarly, the growth rate of general government expenditures is constantly rising with average of $2.7 \%$.

\section{Econometrics Methodology and Results Analysis}

The current paper employs the ARDL approach to examine long-run and short-run relationships between economic growth and fiscal policy instruments (i.e., general government expenditures and total tax rates). The ARDL approach is applied irrespective of whether the variables are co-integrated at $\mathrm{I}(1), \mathrm{I}(0)$ or mutually and can be formulated as in Eq. (3):

$$
\begin{aligned}
\Delta \operatorname{LogGDP}_{\mathrm{t}}=\beta_{0}+\beta_{1 \mathrm{t}} \operatorname{LogGDP}_{\mathrm{t}-1} & +\beta_{2 \mathrm{t}} \operatorname{LogGGE}_{\mathrm{t}-1}+\beta_{3 \mathrm{t}} \operatorname{LogTXR}_{\mathrm{t}-1} \\
& +\sum_{\mathrm{s}=1}^{\mathrm{h}} \beta_{4 \mathrm{~s}} \Delta \operatorname{LogGDP}_{\mathrm{t}-\mathrm{s}}+\sum_{\mathrm{s}=0}^{\mathrm{h}} \beta_{5 \mathrm{~s}} \Delta \operatorname{LogGGE}_{\mathrm{t}-\mathrm{s}}+\sum_{\mathrm{s}=0}^{\mathrm{h}} \beta_{6 \mathrm{~s}} \Delta \operatorname{LogTXR}_{\mathrm{t}-\mathrm{s}}+\varepsilon_{\mathrm{t}}
\end{aligned}
$$

Where $\Delta$ is the first difference operator; $\beta_{0}$ is constant; $\beta_{1} \beta_{2} \beta_{3}$ are for long-run estimates, while other coefficients: $\beta_{4} \beta_{5} \beta_{6}$ are for short-run estimates. For ARDL approach, the first step is to test Eq. (3) by ordinary least square. The null hypothesis of no co-integration is $H_{0}: \beta_{1}=\beta_{2}=\beta_{3}=0$ against alternative $\mathrm{H}_{1}: \beta_{1} \neq \beta_{2} \neq \beta_{3} \neq 0$. The F-statistics is used to test the existence of co-integration among variables. Critical values for F-statistics test are given by Narayan (2005). Pesaran, Shin, and Smith (2001) argued that if the calculated F-statistics value is higher than the upper bound i.e., $\mathrm{I}(1)$, then, the $H_{0}$ of no co-integration is rejected and concludes the existence of co-integration. If 
the calculated F-statistics value is below the lower bound i.e., $\mathrm{I}(0)$, then, the $H_{0}$ of no co-integration is accepted and concludes that there is no long-run relationships among variables. If the calculated F-statistics value is between lower and upper bounds, then results are inconclusive. The VAR model is used to find maximum lag order that was 3 through Akaike information criterion and Schwarz Bayesian criterion as they are ideal for small sample size (i.e., 40 observations). Table 1 shows the results of Kwiatkowski, Phillips, Schmidt, and Shin (KPSS, 1992) unit root test. Economic growth, general government expenditures, and total tax rates are stationary at I( 1$)$.

Table 1. Results of KPSS test

\begin{tabular}{lccccc}
\hline \multirow{2}{*}{ Integration } & Variables & KPSS test statistic & \multicolumn{3}{c}{ KPSS asymptotic critical values } \\
\cline { 4 - 6 } & values & $1 \%$ & $5 \%$ & $10 \%$ \\
\hline \multirow{2}{*}{$(1)$} & LogGDP $_{\mathrm{t}}$ & $0.20^{* *}$ & & & 0.19 \\
& LogGGE $_{\mathrm{t}}$ & $0.18^{*}$ & 0.24 & 0.13 \\
& LogTXR $_{\mathrm{t}}$ & $0.26^{* * *}$ & & & \\
\hline
\end{tabular}

Note. (1) 10 bandwidths used by employing Bartlet Kernel to conduct KPSS test. (2) ${ }^{* * *, * * * *}$ denote statistical significance at the $1 \%, 5 \%$, and $10 \%$ levels, respectively. (3) Author's estimations using E-views software package version 9.0.

Table 2 shows the results of co-integration test. The calculated F-statistic value (5.71) is higher than the upper bound (5.54) at $1 \%$ significance level, showing a co-integration phenomenon between economic growth and fiscal policy tools. The result of co-integration is consistent with results obtained by Osebo (2017) for Ethiopia and by Madni and Chaudhary (2017) for Pakistan.

Table 2. Results of co-integration test

\begin{tabular}{|c|c|c|c|c|c|c|c|}
\hline \multirow{3}{*}{$\begin{array}{l}\text { Function } \\
\operatorname{LogGDP}_{\mathrm{t}}=f\left(\operatorname{LogGGE}_{\mathrm{t}} \& \log _{\mathrm{TXR}}\right) .\end{array}$} & \multirow{3}{*}{$\begin{array}{c}\text { Calculated F-statistic value } \\
5.71^{* * *}\end{array}$} & \multicolumn{6}{|c|}{ Tabulated F-statistics values } \\
\hline & & \multicolumn{2}{|c|}{$1 \%$} & \multicolumn{2}{|c|}{$5 \%$} & \multicolumn{2}{|c|}{$10 \%$} \\
\hline & & $\mathrm{I}(0)$ & $\mathrm{I}(1)$ & $\mathrm{I}(0)$ & $\mathrm{I}(1)$ & $\mathrm{I}(0)$ & $\mathrm{I}(1)$ \\
\hline & & 4.31 & 5.54 & 3.10 & 4.08 & 2.59 & 3.45 \\
\hline
\end{tabular}

Note. (1) The tabulated F-statistics values were retrieved from Narayan (2005, Case II: restricted intercept and no trend, p. 1987). (2) $* * *$ denotes the significance at $1 \%$ level. (3) The computed F-statistic value was obtained from Micro-Fit software package version 5.5.

Once co-integration has been confirmed, next step is to estimate long-run and short-run relationships between economic growth and fiscal policy tools. In Table 3, the long-run and short-run results show that general government expenditures have a positive impact on economic growth, whereas total tax rates have a negative impact. These results are consistent with the Keynesian economic theory. That is, the stimulation of economy can be done either by increasing government expenditure or by a tax cut or both (i.e., expansionary fiscal policy).

Table 3. Long-run and short-run estimation results

\begin{tabular}{lc}
\hline Variable & Coefficient \\
\hline Constant term & $3.660(0.499)$ \\
Long-run: & \\
LogGGE & $5.400^{* *}(0.022)$ \\
LogTXR & $-0.702^{* * *}(0.01)$ \\
Short-run: & \\
$\Delta$ LogGGE $_{\mathrm{t}-1}$ & $0.687(0.811)$ \\
$\Delta$ LogGGE $_{\mathrm{t}-2}$ & $6.411^{* *}(0.015)$ \\
$\Delta$ LogTXR $_{\mathrm{t}-1}$ & $-1.156^{* *}(0.017)$ \\
$\Delta$ LogTXR $_{\mathrm{t}-2}$ & $-7.561(0.115)$ \\
\hline
\end{tabular}

Note. (1) the figures in parentheses are the p-values. (2) ${ }^{* * *}$ and ${ }^{* *}$ represent $1 \%$ and $5 \%$ levels of significance, respectively. (3) Author's estimations using E-views software package version 9.0.

The VECM is employed in this study instead of VAR model because co-integration is confirmed among variables. The negative and significant error correction term (ECT) shows long-run causal relationships, while the F-statistics test illustrates the short-run causality. Eq. (3) can be transformed into an error correction model (ECM) yielding Eq. (4) as the following: 


$$
\left[\begin{array}{c}
\Delta \operatorname{LogG~DP} \\
\Delta \operatorname{LogG~G~E~} \\
\Delta \operatorname{LogTXR}
\end{array}\right]=\left[\begin{array}{c}
a_{1 \mathrm{t}} \\
a_{2 \mathrm{t}} \\
a_{3 \mathrm{t}}
\end{array}\right]+\sum_{\mathrm{s}=0}^{\mathrm{h}}\left[\begin{array}{lll}
\lambda_{11 \mathrm{t}} & \lambda_{12 \mathrm{t}} & \lambda_{13 \mathrm{t}} \\
\lambda_{21 \mathrm{t}} & \lambda_{22 \mathrm{t}} & \lambda_{23 \mathrm{t}} \\
\lambda_{31 \mathrm{t}} & \lambda_{32 \mathrm{t}} & \lambda_{33 \mathrm{t}}
\end{array}\right]\left[\begin{array}{l}
\Delta \operatorname{LogG~DP} \\
\Delta \operatorname{LogG~G~E} \\
\Delta \operatorname{LogTXR}
\end{array}\right]+\left[\begin{array}{c}
\beta_{1 \mathrm{t}} \\
\beta_{2 \mathrm{t}} \\
\beta_{3 \mathrm{t}}
\end{array}\right][\mathrm{EC} \mathrm{T}]_{\mathrm{t}-1}+\left[\begin{array}{c}
\varepsilon_{1 \mathrm{t}} \\
\varepsilon_{2 \mathrm{t}} \\
\varepsilon_{3 \mathrm{t}}
\end{array}\right]
$$

Where $\alpha_{\mathrm{it}}(\mathrm{i}=1, \ldots .3)$ denote the intercept terms; $\lambda_{\mathrm{ijt}}(\mathrm{i}, \mathrm{j}=1, \ldots \ldots 3)$ represent the coefficients to test the $H_{0}$ of no Granger causality in short-run; $\beta_{\text {it }}(\mathrm{i}=1, \ldots . .3)$ denote the coefficients of $\left(\mathrm{ECT}_{\mathrm{t}-1}\right) \mathrm{s}$. These coefficients test the $H_{0}$ of no Granger bidirectional causality in long-run. The results of VECM analysis are given in Table 4. There are bidirectional causal relationships between economic growth and fiscal policy tools in long-run and short-run.

Table 4. Results of VECM Granger causality analysis

\begin{tabular}{|c|c|c|c|c|}
\hline \multirow{3}{*}{ Dependent variables } & \multicolumn{4}{|c|}{ Sources of causation } \\
\hline & \multicolumn{3}{|c|}{ Short-run } & \multirow{2}{*}{$\begin{array}{c}\text { Long-run } \\
\text { ECT }_{\mathrm{t}-1}\end{array}$} \\
\hline & $\Delta \operatorname{LogGDP}_{\mathrm{t}}$ & $\Delta \operatorname{LogGGE} E_{t}$ & $\Delta \log \mathrm{TXR}_{\mathrm{t}}$ & \\
\hline$\Delta \log \mathrm{GDP}_{\mathrm{t}}$ & - & $3.75^{* * *}(0.022)$ & $6.65^{* * * *}(0.01)$ & $-0.90^{* * * *}(0.01)$ \\
\hline$\Delta \operatorname{LogGGE}_{\mathrm{t}}$ & $9.30^{* * * *}(0.005)$ & - & $7.40^{* * * *}(0.007)$ & $-0.80^{* * * *}(0.01)$ \\
\hline$\Delta \log \mathrm{TXR}_{\mathrm{t}}$ & $5.20^{* * *}(0.03)$ & $3.40^{* * *}(0.03)$ & - & $-0.50^{* *}(0.02)$ \\
\hline
\end{tabular}

estimations using E-views software package version 9.0.

\section{Conclusions and Policy Recommendations}

The main objective of this paper is to investigate equilibrium relationships and dynamic causality analyses between economic growth and fiscal policy tools in Jordan for the (1978-2017) period. It employs the ARDL approach and VECM. The results of the KPSS test show that economic growth, general government expenditures, and total tax rates are stationary at $\mathrm{I}(1)$. The results of the bounds F-statistics test under the ARDL approach framework show the existence of a co-integration between variables. The outcomes of the ARDL approach show significant long-run and short-run relationships between economic growth and fiscal policy instruments. The findings of the VECM show bidirectional causal relationships between economic growth and fiscal policy tools.

Based on the results of this study, the following policy recommendations could be drawn:

- The policy makers in the government of Jordan should concentrate on implementing the international monetary fund extended fund facility programs, and the Jordan economic growth plan, 2018-2022. These programs and plan will achieve macroeconomic objectives.

○ The policy makers in the government of Jordan should conduct an expansionary fiscal policy in order to stimulate economic growth in long-run and short-run.

- The general government expenditures should be currently directed to the top two contributing sectors to GDP (i.e., government services and finance).

\section{Acknowledgments}

This work would not have been possible without the financial support of Irbid National University, college of administrative and financial sciences, department of financial and banking sciences, Jordan.

\section{References}

Abu, S. R. (2014). The causal relationship between fiscal policy and economic growth in Jordan. International Journal of Business and Social Science, 5(3), 203-208. Retrieved from https://www.researchgate.net/publication/320584761_The_Causal_Relationship_between_Fiscal_Policy_an d_Economic_Growth_in_Jordan

Al-Fawaz, T. M. (2016). The impact of government expenditures on economic growth in Jordan (1980-2013). International Business Research, 9(1), 99-105. https://doi.org/10.5539/ibr.v9n1p99

Al-Shatti, A. S. (2014). The effects of fiscal policy on economic development in Jordan. International Business Research, 7(12), 67-76. https://doi.org/10.5539/ibr.v7n12p67

Arai, R., Naito, K., \& Ono, T. (2018). Intergenerational policies, public debt, and economic growth: A politico-economic analysis. Journal of Public Economics, 166, 39-52. https://doi.org/10.1016/j.jpubeco.2018.08.006

Attinasi, M. G., \& Klemm, A. (2016). The growth impact of discretionary fiscal policy measures. Journal of Macroeconomics, 49, 265-279. https://doi.org/10.1016/j.jmacro.2016.08.004 
Auteri, M., \& Costantini, M. (2004). Fiscal policy and economic growth: The case of the Italian regions. The $\begin{array}{lllll}\text { Review of Regional } & \text { Studies, } & \text { 34(1), }\end{array}$ file://C:/Users/Dr.\%20Mohamed\%20Mugableh/Downloads/79-Article\%20Text-314-1-10-20120413\%20(2 ) .pdf

Bekhet, H. A., \& Al-Smadi, R. (2017). Exploring the long-run and short-run elasticities between FDI inflow and determinants in Jordan. International Journal of Business and Globalisation, 18(3), 337-362. https://doi.org/10.1504/IJBG.2017.083210

Bekhet, H. A., \& Matar, A. (2013). Co-integration and causality analysis between stock market prices and their determinates in Jordan. Economic Modeling, 35, 508-514. https://doi.org/10.1016/j.econmod.2013.07.012

Bekhet, H. A., \& Mugableh, M. I. (2012). Investigating equilibrium relationships between macroeconomic variables and Malaysian stock market index through bounds tests approach. International Journal of Economics and Finance, 4(10), 69-81. https://doi.org/10.5539/ijef.v4n10p69

Bekhet, H. A., \& Mugableh, M. I. (2013). Examining the equilibrium relationships between foreign direct investment inflows and employment in manufacturing and services sectors: evidence from Malaysia. Journal of Social and Development Sciences, 4(1), 32-38. Retrieved from https://ifrnd.org/journal/index.php/jsds/article/view/733

Bekhet, H. A., \& Mugableh, M. I. (2016). Blueprinting the equilibrium relationships between inward FDI and employment in the Malaysian economic sectors: Time series models approach. Global Business and Economics Review, 18(2), 136-150. https://doi.org/10.1504/GBER.2016.075507

Biolsi, C. (2017). Nonlinear effects of fiscal policy over the business cycle. Journal of Economics Dynamics and Control, 78, 54-87. https://doi.org/10.1016/j.jedc.2017.03.003

Bouakez, H., Chihi, F., \& Normandin, M. (2014). Measuring the effects of fiscal policy. Journal of Economic Dynamics \& Control, 47, 123-151. https://doi.org/10.1016/j.jedc.2014.08.004

Castro, F. D., \& Hernandez de Cos, P. (2008). The economic effects of fiscal policy: The case of Spain. Journal of Macroeconomics, 30, 1005-1028. https://doi.org/10.1016/j.jmacro.2007.08.009

Cyril, U. M. (2016). The effects of fiscal policy on economic growth in Nigeria. Journal of Finance and Accounting, 4(3), 140-145. https://doi.org/10.11648/j.jfa.20160403.16

Ding, Y., McQuoid, A., \& Karayalcin, C. (2018). Fiscal decentralization, fiscal reform, and economic growth in China. China Economic Review, in press, 1-41. https://doi.org/10.1016/j.chieco.2018.08.005

Hamdi, M., Alawin, M., \& Abu Mhareb, E. (2009). Fiscal policy and economic growth: The case of Jordan. International Journal of Applied Business and Economics Research, 7(2), 121-134. Retrieved from https://www.researchgate.net/publication/288804995_Fiscal_policy_and_economic_growth_The_case_of_J ordan

Ialomitianu, R. G., Danu, A. L., \& Bucoi, A. (2016). The effects of fiscal policies on the economic growth in Romania. Bulletin of the Transilvania University of Brasov, 9(2), 291-300. Retrieved from http://webbut.unitbv.ro/BU2016/Series\%20V/BULETIN\%20I/29_Ialomitianu.pdf

Jawadi, F., Mallick, S. K., \& Sousa, R. M. (2016). Fiscal and monetary policies in the BRICS: A panel VAR approach. Economic Modelling, 58, 535-542. https://doi.org/10.1016/j.econmod.2015.06.001

Jordan Economic Growth Plan Report. (2018). Retrieved October 2018 from http://egp.jo/en

Keynes, J. M. (1935). The general theory of employment, interest, and money. Retrieved from http://cas2.umkc.edu/economics/people/facultypages/kregel/courses/econ645/winter2011/generaltheory.pdf

Kwiatkowski, D., Phillips, P. C. B., Schmidt, P., \& Shin, Y. (1992). Testing the null hypothesis of stationary against the alternative of a unit root. Journal of Econometrics, 54, 159-178. https://doi.org/10.1016/0304-4076(92)90104-Y

Lim, G. C., \& McNelis, P. D. (2018). Unconventional monetary and fiscal policies in interconnected economies: Do policy rules matter?. Journal of Economics Dynamics and Control, 93, 346-363. https://doi.org/10.1016/j.jedc.2018.01.028

Madni, G. R., \& Chaudhary, M. A. (2017). Economic growth in context of institutions and fiscal policy. Pakistan $\begin{array}{lllll}\text { Economic and } & \text { Social } & \text { Review, } & \text { 55(1), }\end{array}$ http://econpu.edu.pk/wp-content/uploads/2017/12/5-v55_1_17.pdf 
Mencinger, J., Aristovnik, A., \& Vebric, M. (2017). Asymmetric effects of fiscal policy in EU and OECD countries. Economic Modelling, 61, 448-461. https://doi.org/10.1016/j.econmod.2016.12.023

Mugableh, M. I. (2013). Analysing the $\mathrm{CO}_{2}$ emissions function in Malaysia: Autoregressive distributed lag approach. Procedia Economics and Finance, 5, 571-580. https://doi.org/10.1016/S2212-5671(13)00067-1

Mugableh, M. I. (2015a). Economic growth, $\mathrm{CO}_{2}$ emissions, and financial development in Jordan: Equilibrium and dynamic causality analysis. International Journal of Economics and Finance, 7(7), 98-105. https://doi.org/10.5539/ijef.v7n7p98

Mugableh, M. I. (2015b). Time series analysis of inward foreign direct investment function in Malaysia. Procedia - Social and Behavioral Sciences, 172, 679-685. https://doi.org/10.1016/j.sbspro.2015.01.419

Mugableh, M. I. (2015c). Equilibrium models of the Malaysian stock market and macro economy (1st ed). LAP LAMBERT Academic Publishing. Germany: Berlin.

Mugableh, M. I. (2017a). World oil price volatility and stock returns fluctuations: Evidence from Southeast $\begin{array}{llll}\text { Asian } & \text { equity }\end{array}$ http://www.sci-int.com/pdf/636369163837472289.pdf

Mugableh, M. I. (2017b). Estimating elasticity function of Jordanian aggregate import demand. Applied Economics and Finance, 4(2), 33-37. https://doi.org/10.11114/aef.v4i2.2085

Mugableh, M. I. (2018a). A homoscedastic co-integration analysis of Malaysian financial market. American Journal of Finance and Accounting, 5(4), 360-370. https://doi.org/10.1504/AJFA.2018.093632

Mugableh, M. I., \& Oudat, M. S. (2018b). Economic growth and financial development nexus in Malaysia: Dynamic simultaneous equations models. Asian Journal of Finance \& Accounting, 10(1), 143-161. https://doi.org/10.5296/ajfa.v10i1.12736

Mugableh, M. I., \& Oudat, M. S. (2018c). Modelling the determinants of foreign portfolio investments: A bounds testing and causality analysis for Jordan. Academy of Accounting and Financial Studies Journal, 22(4), 1-8. Retrieved from https://www.abacademies.org/articles/Modelling-The-Determinants-of-Foreign-Portfolio-Investments-15282635-22-4-259.pdf

Narayan, P. K. (2005). The saving and investment nexus for China: Evidence from co-integration tests. Applied Economics, 37(17), 1979-1990. https://doi.org/10.1080/00036840500278103

Ocran, M. K. (2011). Fiscal policy and economic growth in South Africa. Journal of Economic Studies, 38(5), 604-618. https://doi.org/10.1108/01443581111161841

Osebo, G. P. (2017). Fiscal policy and economic growth in Ethiopia. International Journal of African and Asian Studies, 38, 43-57. Retrieved from https://iiste.org/Journals/index.php/JAAS/article/viewFile/38660/39760

Papaioannou, S. K. (2018). The effects of fiscal policy on output: does the business cycle matter? The Quarterly Review of Economics and Finance, in press, 1-10. https://doi.org/10.1016/j.qref.2018.07.006

Pesaran, M. H., Shin, Y., \& Smith, R. J. (2001). Bounds testing approaches to the analysis of level relationships. Journal of Applied Econometrics, 16(3), 289-326. https://doi.org/10.1002/jae.616

Shoayeb Noman, S. M., \& Khudri, M. M. (2015). The effects of monetary and fiscal policies on economic growth in Bangladesh. ELK Asia Pacific Journal of Finance and Risk Management, 6(3), 21-34. https://doi.org/10.16962/EAPJFRM/issn.2349-2317/2015/V6I3-02

World Bank Database. (2018). Retrieved from https://data.worldbank.org/country/jordan

Yang, Z. (2016). Tax reforms, fiscal decentralization, and regional economic growth: New evidence from China. Economic Modelling, 59, 520-528. https://doi.org/10.1016/j.econmod.2016.07.020

Yushkov, A. (2015). Fiscal decentralization and regional economic growth: Theory, empirics, and the Russian experience. Russian Journal of Economics, 1(4), 404-418. https://doi.org/10.1016/j.ruje.2016.02.004

\section{Copyrights}

Copyright for this article is retained by the author(s), with first publication rights granted to the journal.

This is an open-access article distributed under the terms and conditions of the Creative Commons Attribution license (http://creativecommons.org/licenses/by/4.0/). 